\title{
Estimation of Heterosis for Seedling Growth Traits in Gum Arabic Acacia senegal [L.] Wild
}

\author{
Fakuta $\mathrm{NM}^{1}$, Aba $\mathrm{DA}^{2}$, Ado $\mathrm{SG}^{2}$, Usman $\mathrm{IS}^{2}$, and \\ Ojiekpon IF ${ }^{1}$
}

1Rubber Research Institute of Nigeria, Gum Arabic Sub-Station, Gashua, Nigeria. 2Department of Plant Science, Faculty of Agriculture, Institute for Agriculture Research, Ahmadu Bello University, Zaria, Nigeria.

\section{ARTICLE INFO}

Article No.: 031017034

DOI: 10.15580/GJAS.2017.4.031017034

Submitted: 10/03/2017

Accepted: $20 / 03 / 2017$

Published: 01/06/2017

\section{${ }^{*}$ Corresponding Author}

Fakuta NM

E-mail: Fakuta1st @gmail.com

\section{Keywords:}

Gum arabic; Acacia senegal; Provenance; Heterosis; Seedling growth trait

\section{ABSTRACT}

Aiming at estimating heterosis and identifying superior Acacia senegal hybrids, six provenances were selected based on their divergence in gum zinc and manganese concentration and were crossed using in $6 \times 6$ half diallel mating scheme to produce $15 F_{1}$ hybrids. The experiment was conducted in the nursery in Gashua in 2014 and 2015 in a Randomized Complete Block Design (RCBD) replicated three times. Percentage mid-provenance and better- provenance heterosis was estimated for seedling growth traits. Molai x Gajiram1 revealed maximum negative mid-provenance (-71.04\%) and better- provenance $(-77.17 \%)$ heterosis for days to emergence and desirable positive better-provenance heterosis (22.62\%) for canopy diameter. Also Gajiram1 x Molai showed maximum positive mid-provenance heterosis (125.11\%) for number of primary branches while Kukareta $x$ Molai had maximum positive better-provenance heterosis $(88.27 \%)$ for the trait. Damaturu $x$ Molai exhibited highest positive heterosis over mid-provenance $(65.15 \%)$ and better-provenance $(47.30 \%)$ for bark thickness. No significant positive heterosis was observed for seedling height, stem height at first branching and stem diameter at both levels. The hybrids Gajiram1 x Molai, Kukareta $x$ Molai and Damaturu $x$ Molai could be used for future breeding program. 


\section{INTRODUCTION}

Acacia senegal (L.) Willd is a leguminous multipurpose African tree species belonging to the family Fabaceae (FAO, 1997; Dorthe, 2000). Gum arabic is dried exudates obtained from stems and branches of $A$. senegal trees which are cultivated in Africa as a cash crop in agroforestry systems (Duke, 1981). It is a natural product complex mixture of carbohydrate that dissolving freely in water and protein component that does not dissolving in water (FAO, 1990). Gum arabic is approved for use as safe food additive by the US Food and Drug Administration (Dondian and Phillips, 1999). The possible heterosis exploitation for quality traits in $A$. senegal continues to be a critical question. Though previous genetic analyses in trees have indicated that heterosis may be the result of over dominance at several key loci each with an allele inherited from each of parental species, the genetic basis of heterosis in forest trees is often complicated by the long lived, out crossing nature of trees ( $\mathrm{Li}$ and $\mathrm{Wu}, 1996)$. Heterosis over high parent has been reported for seedling height (18.03\%) and stem diameter (8.95\%) across two locations in Acacia senegal (Fakuta et al., 2011). Clonal propagation has also been used to capture hybrid vigor in some forest species of the genus Pinus (Cappa et al., 2013). Hybrid superiority of Populus tremuloides $\times$ P. tremula over $P$. tremuloides for height and diameter growth was evident in the first growing season and persisted in the field (Li et al., 1998). Acacia senegal breeding is a time consuming process due to perenniality. Therefore, genetically superior seedling growth traits are utilized for the exploitation of heterosis and varietal development program. The present study was undertaken to estimate the level of mid- and better-provenance heterosis among $\mathrm{F}_{1}$ hybrids of six $A$. senegal provenances. This information would be useful to investigate the performance and relationship of $F_{1}$ hybrids and provenances and to select suitable parents and population for designing an effective Acacia senegal breeding program.

\section{MATERIALS AND METHODS}

The studies was conducted at the Rubber Research Institute of Nigeria, Gum Arabic Sub-Station Gashua (Latitude $12^{\circ} 45^{\prime} 52^{\prime \prime} \mathrm{N}$ and Longitude $11^{\circ} 00^{\prime} 45^{\prime \prime} \mathrm{E}$ ). Gashua is at an altitude of 360 meters, above sea level and is located within the Sahel savannah ecological zone of Nigeria. Six A. senegal provenances (Kasawa Jakana, Kukareta, Damaturu, Gajiram1, Molai and Dandalmari) were used because of their divergence in gum zinc and manganese composition of total ash and used as parents in a half diallel according to Griffing's method 2, model 1. Hand pollination was done by taking pollen from matured male flowers of the male parent to pollinate the receptive stigma of the chosen female flower of the female parent to generate a $6 \times 6$ half diallel hybrid seeds.

The nursery work which started in April in each year (2014 and 2015) was carried out at the nursery of the Rubber Research Institute of Nigeria, Gum Arabic Sub-Station, Gashua. Polythene bags measuring $7.5 \times$ $20 \mathrm{~cm}$ were filled with potting mixture consisting of topsoil, river sand and cow dung in ratio 2:2:1 and watered once to ease carriage and stacked in a Randomized Complete Block Design (RCBD) in three replications. Each treatment consisted of 20 polythene bags with $30 \times 50 \mathrm{~cm}$ spacing between treatments and replication, respectively. The stacked polythene bags were spread with chlorpyrifos $40 \%$ EC to check termites attack and was watered thoroughly for five days prior to sowing using watering horse to stabilize the soil and improve seed-soil contact after sowing. To enhance vigorous seed germination and development, pregermination treatment was done by soaking the $15 \mathrm{~F} 1$ hybrids and the six provenances seeds in tap water for 24 hours at room temperature before sowing. Two seeds of each genotype were sown directly in each polythene bag by hand at a depth of $1 \mathrm{~cm}$ and were thinned down to one plant per polyethylene bag. The polyethylene bags were watered twice a day except on days with rainfall. All nursery practices were carried out as recommended by Ojiekpon et al. (2011).

The seedling growth traits were measured monthly starting from one month after sowing (MAS) for up to three MAS. Measurements were carried out on four inner seedlings in each replication. The following traits were measured at nursery level: 1. Days to emergence (No): Appearance of seedlings cotyledon was an evidence of emergence and the day it occurred in relation to sowing date was recorded as days to emergence. 2. Seedling height $(\mathrm{cm})$ : Seedling height was determined by measuring from root collar of seedling to the top of the apical bud using measuring tape. 3. Canopy diameter $(\mathrm{cm})$ : Average canopy diameter, measured as the distance from the widest part of the seedling canopy in two dimensions parallel to the row and perpendicular to the row using measuring tape. 4. Number of primary branches (No): The number of primary branches was obtained by counting the number of each branch attached to the main stem of the seedling. 5. Stem height at first branching $(\mathrm{cm})$ : This was measured from the seedling root collar to the first primary branch of the seedling using measuring tape. 6 . Bark thickness $(\mathrm{cm})$ : Bark thickness was recorded by cutting and removing a portion of the stem bark of the seedling using razor blade and the thickness measured using digital vernier caliper. 7. Stem diameter $(\mathrm{cm})$ : The stem was measured at the root collar of the seedling directly above soil line using digital vernier caliper. To estimate significant differences among provenances and $F_{1}$ hybrids, the data were subjected to analysis of variance; by using the analysis of variance technique (Steel \& Torrie, 1980). Means were compared using 
least significant difference (LSD). The data were analyzed using the general linear model procedure of statistics analysis system software version 9.0 (SAS, 2002). Heterosis was computed as the percentage of superiority of the hybrid over its mid-provenance value (MP \%) or better-provenance value (BP \%) (ljaz et al., 2002).

Better-provenance Heterosis $=\frac{F_{1}-B_{p}}{B_{P}} \times 100$

Mid-provenance Heterosis $=\frac{F_{1}-M_{p}}{M_{p}} \times 100$

Where $F_{1}=$ Mean performance of hybrid

$H_{p}=$ Mean performance of better-provenance

$M_{p}=$ Mean of mid-provenance
Significance of mid- and better-provenance heterosis was determined using 't' test suggested by Wynne et al. (1970).

$S . E .(M P)=M_{p} / \sqrt{\frac{3}{6} E M S}$ and $S . E .(B P)=B_{p} / \sqrt{\frac{1}{2}} E M S$

RESULTS

The analysis for days to emergence seedling height, canopy diameter, number of primary branches, stem height at first branching, bark thickness and stem diameter combined across 2014 and 2015 at Gashua are presented in Table 1 . The mean squares due to genotypes were highly significant $(P<0.01)$ for all traits, indicating that the genotypes under study are highly variable.

Table 1: Mean squares for seedling growth traits of $A$. senegal combined across 2014 and 2015 nurseries at Gashua

\begin{tabular}{lllllllll}
\hline SV & df & DTEM & SDHT & CDM & NPB & SHFB & BKTN & STDM \\
\hline Year & 1 & $0.22^{\text {ns }}$ & $127.42^{\text {ns }}$ & $652.36^{* *}$ & $0.29^{\text {ns }}$ & $0.11^{\text {ns }}$ & $0.0001^{\text {ns }}$ & $0.003^{\text {ns }}$ \\
Rep(Year) & 4 & $1.09^{\text {ns }}$ & $163.40^{\star *}$ & $22.78^{\text {ns }}$ & $0.71^{\text {ns }}$ & $13.58^{\text {ns }}$ & $0.0003^{\text {ns }}$ & $0.003^{\text {ns }}$ \\
Genotypes & 20 & $18.07^{\star *}$ & $247.35^{\star *}$ & $175.07^{\star *}$ & $56.94^{\star *}$ & $31.50^{\star *}$ & $0.004^{\star *}$ & $0.018^{* *}$ \\
Error & 80 & 1.01 & 41.73 & 16.84 & 1.92 & 7.06 & 0.0002 & 0.0031 \\
\hline$*{ }^{* *}$ and ns & significant at 0.05, significant & at 0.01 & &
\end{tabular}

${ }^{*},{ }^{* *}$ and $\mathrm{ns}=$ significant at 0.05 , significant at 0.01 level of probability and non significant, respectively. $\mathrm{SV}=$ Source of variation, DTEM=days to emergence, SDHT=seedling height, CDM=canopy diameter, $\mathrm{NPB}=$ number of primary branches, SHFB=stem height at first branching, BKTN=bark thickness, STDM=stem diameter. 
Table 2: Mean performance of provenances and their hybrids for seedling growth traits of $\boldsymbol{A}$. senegal combined across 2014 and 2015 nurseries at Gashua

\begin{tabular}{|c|c|c|c|c|c|c|c|}
\hline Provenances & $\begin{array}{l}\text { DTEM } \\
\text { (no) }\end{array}$ & $\begin{array}{l}\text { SDHT } \\
(\mathrm{cm})\end{array}$ & $\begin{array}{l}\text { CDM } \\
(\mathrm{cm})\end{array}$ & $\begin{array}{l}\text { NPB } \\
\text { (no) }\end{array}$ & $\begin{array}{l}\text { SHTB } \\
(\mathrm{cm})\end{array}$ & $\begin{array}{l}\text { BKTN } \\
(\mathrm{cm})\end{array}$ & $\begin{array}{l}\begin{array}{l}\text { STDM } \\
(\mathrm{cm})\end{array} \\
\end{array}$ \\
\hline Kasawa Jakana & 7.30 & 42.73 & 21.81 & 4.66 & 9.37 & 0.12 & 0.68 \\
\hline Kukareta & 9.28 & 49.11 & 34.33 & 8.24 & 11.13 & 0.16 & 0.69 \\
\hline Damaturu & 7.81 & 55.69 & 24.02 & 7.46 & 12.76 & 0.12 & 0.72 \\
\hline Gajiram1 & 8.34 & 40.42 & 18.88 & 5.04 & 5.77 & 0.09 & 0.57 \\
\hline Molai & 4.81 & 33.85 & 16.34 & 8.08 & 4.61 & 0.10 & 0.64 \\
\hline $\begin{array}{l}\text { Dandalmari } \\
\text { Hybrids }\end{array}$ & 8.79 & 54.13 & 33.96 & 6.39 & 6.92 & 0.15 & 0.75 \\
\hline Kasawa Jakana x Kukareta & 8.27 & 35.97 & 32.38 & 6.85 & 10.44 & 0.16 & 0.63 \\
\hline Kasawa Jakana x Damaturu & 7.69 & 44.54 & 28.29 & 5.17 & 6.63 & 0.12 & 0.69 \\
\hline Kasawa Jakana x Gajiram1 & 5.63 & 41.85 & 25.84 & 6.17 & 9.58 & 0.14 & 0.62 \\
\hline Kasawa Jakana x Molai & 7.43 & 34.29 & 24.40 & 9.41 & 5.11 & 0.10 & 0.57 \\
\hline Kasawa Jakana x Dandalmari & 7.08 & 46.33 & 30.57 & 8.77 & 8.15 & 0.14 & 0.71 \\
\hline Kukareta x Damaturu & 7.16 & 51.04 & 25.04 & 8.11 & 9.18 & 0.17 & 0.65 \\
\hline Kukareta x Gajiram1 & 4.74 & 39.05 & 24.47 & 10.71 & 7.83 & 0.15 & 0.67 \\
\hline Kukareta x Molai & 5.16 & 39.47 & 24.11 & 15.52 & 4.82 & 0.14 & 0.61 \\
\hline Kukareta x Dandalmari & 8.26 & 50.23 & 35.65 & 6.29 & 7.92 & 0.17 & 0.71 \\
\hline Damaturu x Gajiram1 & 7.06 & 46.27 & 23.73 & 5.01 & 7.09 & 0.11 & 0.61 \\
\hline Damaturu x Molai & 8.37 & 40.67 & 23.69 & 13.26 & 6.37 & 0.18 & 0.58 \\
\hline Damaturu x Dandalmari & 8.26 & 44.31 & 22.00 & 8.75 & 9.66 & 0.17 & 0.58 \\
\hline Gajiram1 x Molai & 1.91 & 35.19 & 23.15 & 14.78 & 4.05 & 0.12 & 0.60 \\
\hline Gajiram1x Dandalmari & 6.65 & 37.98 & 19.74 & 6.25 & 7.79 & 0.12 & 0.63 \\
\hline Molai x Dandalmari & 6.15 & 38.19 & 18.74 & 8.27 & 9.27 & 0.10 & 0.57 \\
\hline Mean & 6.96 & 42.92 & 25.29 & 8.25 & 7.83 & 0.13 & 0.64 \\
\hline $\operatorname{LSD}(0.01)$ & 0.82 & 5.27 & 3.35 & 1.13 & 2.17 & 0.01 & 0.05 \\
\hline CV (\%) & 14.43 & 15.05 & 16.23 & 16.78 & 33.93 & 9.87 & 8.67 \\
\hline
\end{tabular}

DTEM=days to emergence, SDHT=seedling height, NPB=number of primary branches, SHFB=stem height at first branching, BKTN=bark thickness, STDM=stem diameter.

The mean performance of provenances and their hybrids for seedlings growth traits combined across 2014 and 2015 are presented in Table 2. Molai provenance had the shortest days to emergence. Damaturu and Dandalmari though statistically comparable had tallest seedlings compared to the rest of the provenances. Kukareta and Dandalmari recorded the widest canopy diameter. Kukareta and Molai though statistically similar gave the highest number of primary branches compared to Kasawa Jakana and Gajiram1. The tallest stem height at first branching was recorded for Damaturu and Kukareta. For the trait bark thickness Kukareta and Dandalmari were the thickest. Provenances Dandalmari, Damaturu, Kukareta and Kasawa Jakana though statistically comparable had significantly wider stem diameter than Gajiram1 and Molai that appear weak in their performance with respect to most of the traits studied. The hybrids Gajiram1 x Molai, Kukareta x Gajiram1, Kukareta x Molai, Kasawa Jakana x Gajiram1 and Molai $x$ Dandalmari recorded the lowest number of days to emerge while the rest of the hybrids took seven days or more before emergence. Hybrids Kukareta $x$
Damaturu and Kukareta $x$ Dandalmari though statistically similar recorded the tallest seedlings compared to the rest of the provenances which were statistically comparable. Kukareta $\times$ Dandalmari showed the widest canopy diameter while the rest of the hybrid had similar canopy sizes. Statistically higher numbers of primary branches were recorded for Kukareta $x$ Molai, Gajiram1 x Molai, Damaturu x Molai and Kukareta $\mathrm{x}$ Gajiram1 compared to the rest of the hybrids. Kasawa Jakana $x$ Kukareta though statistically comparable with most of the hybrids resulted in taller stems at first branching compared to Gajiram1 x Molai and Kasawa Jakana $x$ Molai that recorded the shortest stems. Hybrids Damaturu $x$ Molai, Kukareta $x$ Damaturu, Kukareta $x$ Dandalmari, Damaturu $x$ Dandalmari and Kasawa Jakana $x$ Kukareta had thicker barks compared to the rest of the hybrids that were statistically similar. Kasawa Jakana $x$ Dandalmari and Kukareta $x$ Dandalmari showed the highest mean values for stem diameter while Kasawa Jakana x Molai, Damaturu $x$ Molai and Molai $x$ Dandalmari recorded the lowest mean 
values compared to the rest of the hybrids that had similar stem sizes.

The coefficient of variation (CV) estimates were highest for stem height at first branching (33.93\%), followed by number of primary branches (16.78\%), seedlings height $(15.05 \%)$, days to emergence $(14.43 \%)$, bark thickness $(9.87 \%)$ and the lowest was recorded for stem diameter (8.67\%).

The estimates of percentage heterosis for $15 \mathrm{~F}_{1}$ hybrids over mid- and better-provenances for seedling growth traits combined across 2014 and 2015 nurseries at Gashua are presented in Table 3.

Days to emergence. Out of the 15 hybrids, seven showed significant mid-provenance heterosis of which five showed negative and two showed positive for days to emergence. The five significant mid-provenance heterosis were recorded for Gajiram 1 x Molai, Kukareta x Gajiram1, Kasawa Jakana x Gajiram1, Kukareta x Molai and Gajiram1 x Dandalmari while Kasawa Jakana $x$ Molai and Damaturu x Molai expressed significant positive mid-provenance heterosis for the trait. Despite the fact that no hybrid showed significant positive betterprovenance heterosis, Gajiram1 x Molai, Kukareta $\mathrm{x}$ Gajiram1, Kukareta x Molai, Kasawa Jakana x Gajiram1, Molai x Dandalmari, Gajiram1 x Dandalmari, Kukareta $x$ Damaturu and Kasawa Jakana $x$ Dandalmari had significant negative better-provenance heterosis in the right direction for achieving early seed emergence in $A$. senegal.

Seedling height. Out of the 15 hybrids none expressed significant positive mid-provenance heterosis for seedling height in combined results (Table 3). However, hybrids Kasawa Jakana x Kukareta, Damaturu $x$ Dandalmari and Gajiram1 x Dandalmari expressed significant negative heterosis for the trait. Betterprovenance heterosis recorded negative values for all the 15 hybrids (Table 3 ). The significant negative betterprovenance heterosis for seedling height ranged from $16.92 \%$ to $-29.83 \%$.

Canopy diameter. Mid-provenance heterosis for canopy diameter revealed four significant positive hybrids and three significant negative hybrids (Table 3). Kasawa Jakana $x$ Damaturu, Kasawa Jakana $x$ Gajiram1, Kasawa Jakana x Molai and Gajiram1 x Molai showed significant positive heterosis while Damaturu $x$ Dandalmari, Gajiram1 x Dandalmari and Molai $x$ Dandalmari recorded significant negative heterosis. For better- provenance heterosis, Gijaram 1 x Molai (22.62\%) was significantly positive while hybrids Gajiram1 x Dandalmari, Molai $x$ Dandalmari, Damaturu $x$ Dandalmari, Kukareta x Molai, Kukareta x Gajiram1 and Kukareta $\mathrm{x}$ Damaturu showed significant negative for Canopy diameter (Table 3).

Table 3: Estimates of percentage mid-provenances heterosis (MPH) and better-provenance heterosis (BPH) for 15 hybrids seedlings growth traits of $A$. senegal combined across 2014 and 2015 nurseries at Gashua

\begin{tabular}{|c|c|c|c|c|c|c|c|c|}
\hline \multirow[b]{2}{*}{$F_{1}$ hybrids } & \multicolumn{2}{|c|}{ DTEM(no) } & \multicolumn{2}{|c|}{$\mathrm{SDHT}(\mathrm{cm})$} & \multicolumn{2}{|c|}{$\operatorname{CDM}(\mathrm{cm})$} & \multicolumn{2}{|c|}{$\mathrm{NPB}(\mathrm{no})$} \\
\hline & MPH & $\mathrm{BPH}$ & MPH & $\mathrm{BPH}$ & MPH & $\mathrm{BPH}$ & MPH & $\mathrm{BPH}$ \\
\hline $\begin{array}{l}\text { Kasawa Jakana } x \\
\text { Kukareta }\end{array}$ & -0.20 & -10.84 & $-21.67^{*}$ & $-26.75^{\star \star}$ & 15.36 & -5.69 & 6.12 & -16.93 \\
\hline $\begin{array}{l}\text { Kasawa Jakana x } \\
\text { Damaturu } \\
\text { Kasawa Jakana x }\end{array}$ & 1.82 & -1.52 & -9.49 & $-20.02^{*}$ & 23.46 & 17.77 & -14.71 & $-30.70^{*}$ \\
\hline Gajiram1 & $-27.97^{\star *}$ & $-32.48^{\star *}$ & 0.67 & -2.06 & 27.00 & 18.46 & 27.08 & 22.27 \\
\hline $\begin{array}{l}\text { Kasawa Jakana x Molai } \\
\text { Kasawa Jakana x }\end{array}$ & $22.75^{\star *}$ & 1.85 & -10.44 & -19.74 & 27.92 & 11.87 & $47.69^{* *}$ & 16.43 \\
\hline Dandalmari & -11.96 & $-19.45^{*}$ & -4.33 & -14.40 & 9.61 & -10.00 & $58.62^{* *}$ & $37.18^{*}$ \\
\hline Kukareta x Damaturu & -16.20 & $-22.82^{* *}$ & -2.60 & -8.35 & -14.16 & $-27.05^{\star \star}$ & 3.33 & -1.58 \\
\hline Kukareta x Gajiram1 & $-46.19^{* *}$ & $-48.90^{* *}$ & -12.77 & $-20.49^{*}$ & -8.02 & $-28.73^{\star \star}$ & $61.21^{\star \star}$ & $29.93^{*}$ \\
\hline Kukareta x Molai & $-26.80^{\star *}$ & $-44.40^{* *}$ & -4.84 & $-19.63^{*}$ & -4.84 & $-29.79^{\star \star}$ & $90.10^{\star \star}$ & $88.27^{\star \star}$ \\
\hline Kukareta $\times$ Dandalmari & -8.57 & -10.94 & -2.69 & -7.20 & 4.41 & 3.84 & -14.02 & -23.68 \\
\hline $\begin{array}{l}\text { Damaturu x Gajiram1 } \\
\text { Damaturu x Molai }\end{array}$ & $\begin{array}{l}-12.65 \\
32.56^{\star *}\end{array}$ & $\begin{array}{r}-15.44 \\
7.13\end{array}$ & $\begin{array}{l}-3.71 \\
-9.16\end{array}$ & $\begin{array}{l}-16.92^{\star} \\
-26.97^{\star \star}\end{array}$ & $\begin{array}{l}10.64 \\
17.39\end{array}$ & $\begin{array}{l}-1.21 \\
-1.39\end{array}$ & $\begin{array}{l}-19.88 \\
70.57^{\star \star}\end{array}$ & $\begin{array}{l}-32.85^{*} \\
63.98^{* *}\end{array}$ \\
\hline Damaturu x Dandalmari & -0.52 & -6.08 & $-19.30^{*}$ & $-20.43^{*}$ & $-24.11^{*}$ & $-35.21^{* *}$ & 26.37 & 17.32 \\
\hline Gajiram1 x Molai & $-71.04^{* *}$ & $-77.17^{\star *}$ & -5.23 & -12.93 & 31.47 & $22.62^{*}$ & $125.11^{* *}$ & $82.78^{* *}$ \\
\hline Gajiram1x Dandalmari & $-22.43^{\star *}$ & $-24.41^{* *}$ & $-19.65^{*}$ & $-29.83^{\star *}$ & $-25.30^{*}$ & $-41.89^{* *}$ & 9.33 & -2.19 \\
\hline Molai $\times$ Dandalmari & -9.55 & $-30.02^{* *}$ & -13.18 & $-29.44^{\star \star}$ & $-25.47^{*}$ & $-44.81^{\star *}$ & 14.21 & 2.25 \\
\hline
\end{tabular}


Table 3: continued

\begin{tabular}{|c|c|c|c|c|c|c|}
\hline \multirow[b]{2}{*}{$F_{1}$ hybrids } & \multicolumn{2}{|c|}{$\mathrm{SHFB}(\mathrm{cm})$} & \multicolumn{2}{|c|}{$\mathrm{BKTN}(\mathrm{cm})$} & \multicolumn{2}{|c|}{$\operatorname{STDM}(\mathrm{cm})$} \\
\hline & $\mathrm{MPH}$ & $\mathrm{BPH}$ & $\mathrm{MPH}$ & $\mathrm{BPH}$ & $\mathrm{MPH}$ & $\mathrm{BPH}$ \\
\hline Kasawa Jakana x Kukareta & 1.88 & -6.17 & 9.41 & -1.84 & -7.20 & -7.77 \\
\hline Kasawa Jakana x Damaturu & $-40.03^{*}$ & $-47.99^{\star *}$ & 1.37 & 2.78 & -1.31 & -3.95 \\
\hline Kasawa Jakana x Gajiram1 & 26.54 & 2.26 & $36.59^{\star *}$ & $16.67^{\star}$ & -0.27 & -8.11 \\
\hline Kasawa Jakana x Molai & -26.83 & $-45.41^{*}$ & -7.69 & $-16.67^{\star}$ & $-14.29^{\star}$ & $-16.71^{\star *}$ \\
\hline Kasawa Jakana x Dandalmari & 0.11 & -12.99 & 6.17 & -4.44 & -0.93 & -5.57 \\
\hline Kukareta x Damaturu & -23.12 & -28.03 & $15.12^{*}$ & 4.29 & -7.13 & -9.07 \\
\hline Kukareta x Gajiram1 & -7.36 & -29.65 & $18.12^{*}$ & -10.02 & 5.70 & -3.16 \\
\hline Kukareta x Molai & -38.78 & $-56.70^{\star *}$ & 6.41 & $-15.13^{*}$ & -8.04 & -11.17 \\
\hline Kukareta $x$ Dandalmari & -12.25 & -28.85 & 6.38 & 2.25 & -1.05 & -5.12 \\
\hline $\begin{array}{l}\text { Damaturu x Gajiram1 } \\
\text { Damaturu x Molai }\end{array}$ & $\begin{array}{l}-23.43 \\
-26.69\end{array}$ & $\begin{array}{l}-44.39^{\star *} \\
-50.10^{\star *}\end{array}$ & $\begin{array}{l}5.60 \\
65.15^{\star *}\end{array}$ & $\begin{array}{l}-10.81 \\
47.30^{\star *}\end{array}$ & $\begin{array}{l}-6.08 \\
-14.50^{\star}\end{array}$ & $\begin{array}{l}-15.58^{* *} \\
-19.07\end{array}$ \\
\hline Damaturu x Dandalmari & -1.78 & -24.26 & $23.17^{\star \star}$ & 12.22 & $-21.05^{\star *}$ & $-22.72^{\star *}$ \\
\hline Gajiram1 x Molai & -21.98 & -29.83 & $32.11^{\star \star}$ & $24.14^{*}$ & -0.41 & -5.73 \\
\hline Gajiram1x Dandalmari & 22.78 & 12.63 & 3.55 & $-18.89^{* *}$ & -5.05 & $-16.26^{\star \star}$ \\
\hline Molai x Dandalmari & 60.78 & 33.98 & $-18.92^{*}$ & $-33.33^{\star *}$ & $-17.41^{\star *}$ & $-23.39^{\star *}$ \\
\hline
\end{tabular}

Number of primary branches: Out of 12 positive hybrids, six exhibited significant mid-provenance heterosis for the trait. The performances of the hybrids in order of decreasing magnitude were: Gajiram 1 x Molai (125.11\%), Kukareta x Molai, Damaturu x Molai, Kukareta $x$ Gajiram1, Kasawa Jakana $x$ Dandalmari and Kasawa Jakana x Molai (47.69\%) (Table 3). There was no significant negative mid-provenance heterosis for the trait. For better-provenance heterosis, nine hybrids showed positive values and five were significant whereas six hybrids recorded negative values and two were significant (Table 3 ). The positive betterprovenance heterotic effects for number of primary branches ranged from $29.92 \%$ to $82.78 \%$ while the negative heterotic effects ranged between $-30.70 \%$ and $32.85 \%$ for the trait.

Stem height at first branching: Among the 15 hybrids, one hybrid each recorded significant positive and significant negative mid-provenance heterosis for the trait (Table 3). Molai x Dandalmari $(60.78 \%)$ showed positive value while Kasawa Jakana $x$ Damaturu $(-40.03 \%)$ showed negative value. Better- provenance heterosis occurrence in the 15 hybrids revealed three were positive, none was significant and twelve were negative of which five were significant (Table 3). Kasawa Jakana x Damaturu, Kasawa Jakana x Molai, Kukareta x Molai, Damaturu $x$ Gajiram1 and Damaturu $x$ Molai recorded significant negative better- provenance heterosis for the trait.

Bark thickness: It was observed that among the 13 hybrids with positive values, six were significant and ranged from $15.12 \%$ to $65.15 \%$ (Table 3). Also, among the two hybrids with negative values, Molai $x$ Dandalmari recorded significant heterosis of $-18.92 \%$. Betterprovenance heterosis for bark thickness recorded three significant positive hybrids and four significant negative hybrids. Damaturu x Molai $(47.30 \%)$ showed highest positive heterosis while Kasawa Jakana $x$ Gajiram1 $(16.67 \%)$ showed the lowest. Also, Kasawa Jakana $x$ Molai $\quad(-33.33 \%)$ had highest negative heterosis while Molai $x$ Dandalmari $(-15.13 \%)$ had the lowest for the trait.

Stem diameter: Out of the 15 hybrids, only Kukareta $x$ Gajiram1 expressed not significant positive midprovenance heterosis for stem diameter (Table 3). Conversely, hybrids Kasawa Jakana x Molai, Damaturu $x$ Molai, Damaturu x Dandalmari and Molai x Dandalmari showed significant negative mid-provenance heterosis ranged between $-14.29 \%$ and $-21.05 \%$. For betterprovenance heterosis, none of the hybrids showed positive values (Table 3). However, five out of 15 hybrids expressed highly significant negative heterosis for stem diameter. 


\section{DISCUSSION}

The analysis of variance suggested that provenance population was highly variable and therefore would likely respond to selection. The comparative mean performance of the parental provenances and hybrids indicated superiority for some of the genotypes over others. Good potential exists for Molai provenance in terms of early days to emergence across year. Seed dormancy is an innate character of $A$. senegal seed because it takes a long period of time to finish emergence (Ojiekpon et al., 2011). Damaturu and Dandalmari provenances expressed seedling height superiority compared to all the genotypes across years. Seedling height is an important trait to select for early tapping maturity in A.senegal (Jamal and Huntsinger, 1993). Kukareta showed distinct canopy diameter, number of primary branches and bark thickness while Damaturu had been identified for stem height at first branching and stem diameter. The superior growth traits of these provenances are not surprising as variability in growth among provenance population of $A$. senegal has been very well documented (Anders et al., 2003). Similarly some hybrids expressed superiority with respect to some of the traits. Gajiram1 x Molai was distinct for early days to emergence while the hybrids Kukareta $\times$ Damaturu and Kukareta $\times$ Dandalmari were superior for seedling height. Kukareta $x$ Dandalmari also recorded the widest seedling canopy, Kukareta $x$ Molai had the highest number of primary branches, Damaturu $x$ Molai for bark thickness and Kasawa Jakana $x$ Dandalmari recorded superior stem diameter in the combined years. Depending on the breeding objectives, there are wide variety of provenances and hybrids to choose from. Most tree breeding projects utilize the selection of the best performing seedlings, concerning agriculturally important traits (Emanuel and Eli, 1995). In $A$. senegal, early tapping maturity was indicated by tree height and stem diameter, therefore the hybrid Kukareta $x$ Damaturu whose parental provenances were selected based on superior gum quality might be a good hybrid for earliness and desired gum quality.

\section{Heterosis}

The appearance of all $F_{1}$ showed variation in all the traits. The use of the same provenance produced divergent progeny performance. This is understandable because $A$. senegal is a heterozygous and naturally cross pollinated tree. Thus, hybrids from their crosses were unpredictable. This is presumably because of the influence of pleiotropy and genetic linkage (Lavi et al., 1998). Gajiram1 x Molai expressed highly significant negative mid-provenance and better-provenance heterosis for days to emergence with respective values of $-71.04 \%$ and $-77.17 \%$ which could be exploited for early emergence. Similarly, Kukareta x Damaturu had highly significant negative heterotic effects of $-22.82 \%$ for days to emergence; this is useful because both provenances involved in this hybrid were selected for their good gum zinc and manganese concentration.

Height is an essential trait to determine early tapping maturity in gum arabic tree. However, significant positive heterosis was not recorded for the trait. Johnsen et al. (1998) suggested that genetic variation in height of artificially produced population could be under additive gene control. The significant negative mid- and betterprovenance heterosis expressed by Kasawa Jakana $x$ Kukareta and Damaturu x Dandalmari and Gajiram1 $x$ Dandalmari for seedling height agrees with reports of Manley and Ledig (1979) on negative heterosis for seedling growth in red spruce and Lopez-Upton et al. (1999) for early growth traits in $F_{1}$ hybrid of loblolly and slash pine.

Canopy diameter is an important factor for tree growth which determines the amount of solar radiation intercepted by a tree for photosynthesis (Toma, 2013) that resulted in gum formation and translocated to the stem and branches (Fagg and Allison, 2004). Gajiram1 x Molai expressed significant positive mid-provenance and better-provenance heterosis for canopy diameter and both provenances were selected for high gum zinc and manganese concentration. This underscores the favourable and beneficial contribution of hybridization in transferring desirable genes from parents to their hybrids (Amiri-Oghan et al., 2009).

Hybrids Kasawa Jakana x Dandalmari, Kukareta $x$ Molai, Kukareta x Gajiram1 and Damaturu x Molai showed significant heterotic response for number of primary branches, in each hybrid a provenance selected for high gum zinc and manganese concentration was involved. Also Molai x Dandalmari had mid-provenance heterosis of $60.78 \%$ for stem height at first branching. Heterosis has been documented in branch habit of Populus (Brandshaw and Stettler, 1995).

The report by Anderson (1995) indicated that gum is found immediately under the bark and is formed within the tree by the metamorphosis of the cells of the inner bark. In the light of this, the combined midprovenance and better-provenance heterosis achieved by Kasawa Jakana $x$ Gajiram1, Damaturu $x$ Molai and Gajiram1 x Molai could be utilized for thick bark improvement although each of the hybrids had provenance selected for high gum zinc and manganese concentration.

No hybrids recorded significant positive heterosis for stem diameter in the nursery. This is indicative of the naturally cross pollinated species whose hybrids performance could be unpredictable most probably due to the decrease in effectiveness of the alleles when they are joined together in one genotype. These decreases provide cases of negative heterosis due to heterozygosity at a single locus (Sukartini et al., 2012) or the traits may be under additive gene control as suggested by Johnsen et al. (1998).

\section{CONCLUSION}


It is concluded from present study that the heterotic values for early emergence, canopy diameter, number of primary branches and bark thickness in relation to midand better-provenance indicated increase. Thus, dominance genetic control was able to influence the traits in $A$. senegal seedlings. The hybrids Gajiram1 $\mathrm{x}$ Molai, Kukareta $x$ Molai and Damaturu x Molai could further be evaluated for early seedling growth due to their high heterotic values for days to emergence, canopy diameter, number primary branches and bark thickness.

\section{REFERENCE}

Anders, R., Lars, G. and Lambart, G.O. (2003) Evaluation of provenance trial of Acacia senegal at Gonse Burkina Faso. Trial No. 12 in the Arid Zone Series, Danida Forest Seed Centre, Denmark and Food and Agriculture Organization, Rome, No. 5: 1- 41

Amiri-Oghan, H., Fotokian, M. H., Javidfa, F. and Alizadeh, B. (2009). Genetic analysis of grain yield, days to flowering and maturity in oilseed rape ( $B$. napus $L$.) using diallel crosses. International Journal of Plant production, 3(2):1926

Anderson, D. M.W. (1995). Gums-Ancient and modern commercial products. NFT Highlights NFTA 95-01, Winrock International, Arkansas, USA

Bradshaw, H.D. and Stettler, R. F. (1995). Molecular genetics of growth and development in Populus. IV. Mapping QTLs with large effects on growth, form and phenology traits in a forest tree. Genetics,139: 963-973

Cappa, E. P., Martín-Marcó, D., Nikles, G. and lan, S. (2013) Last performance of Pinus elliottii, Pinus caribaea, their $\mathrm{F}_{1}$, $\mathrm{F}_{2}$ and backcross hybrids and Pinus taeda to 10 years in the Mesopotamia region, Argentina. New Forest, 44:197218

Dondain, G. and Phillips, G. O. (1999). The regulatory journey of gum arabic. Journal of Foods and Food Ingredients, 179: 38-56.

Dorthe, J. (2000). Acacia senegal (L) Willd seed leaflet. Danida Forest Seed Center, Denmark. No. 5:1-2.

Duke, J. A. (1981). Handbook of Legumes of World Economic Importance. Plenum Press, New York. pp. 338-344

Emanuel, L., and Eli, T. (1995). Performance of Avocado (Persea Americana Mill.) and Mango (Mangifera indica L.) Seedlings Compared with Their Grafted Trees. Journal of American Society of Horticultural Science, 120 (2): 265269.

Fagg, C.W. and Allison, G. E. (2004). Acacia senegal (L.) Willd and the gum arabic trade. Oxford Institute Tropical Forest Papers, 42: 6-8.

FAO (1990). Specification for identity and purity of certain food additives, Food and Nutrition paper No.52 (Addendum 7), FAO, Rome. 49: 23.
FAO (1997). Food and Nutrition. Food and Agriculture Organization of the United Nation, $\quad$ Rome 52:5.

Fakuta, N. M., Kadams, A. M., Ojiekpon, I. F., Abubakar, M. and Jatto, M. I. (2011). Heterosis and combining ability of $\mathrm{F}_{1}$ hybrid in provenance populations of gum arabic (Acacia senegal (L.) Willd). ChemTech Journal, 7:139-145

ljaz, R., Abdulsalam, K. and Zulfiqar, A. (2002). Estimation of heterosis for yield and some yield components in bread wheat. International Journal of agriculture and Biology, 4 (2):214-216.

Jamal, A. and Huntsinger, L. (1993). Deterioration of a sustainable agro-silvo-pastoral system in the Sudan: the gum gardens of Kordofan. Agroforestry Systems, 23: 2338.

Johnsen, K. H., Major, J. E., Loo, J. and McPhee, D. (1998). Negative heterosis not apparent in 22-year-old hybrid of Picea maria and Picea rubens. Canadian Journal of Botany, 76: 434-439.

Lavi, U., Tomer, E., Gazit, S. and Hille, J. (1998). Component of the genetic variance and genetic correlations between traits in mango. Scientia Horticulturae, 75: 11-25.

$\mathrm{Li}, \mathrm{B}$. and R. Wu. (1996). Genetic cause of heterosis in juvenile aspen: a quantitative comparison across intra- and interspecific hybrids. Theoretical and Applied Genetics, 93:380391.

Li, B., Howe, T.G and Wu, R. (1998). Developmental factors responsible for heterosis in aspen hybrids (Populus tremuloides x P. Tremula). Tree Physiology, 18: 29--36

Manley, S.A.M., and Ledig, F.T. (1979). Photosynthesis in black and red spruce and their hybrid derivatives: ecological isolation and hybrid adaptive inferiority. Canadian Journal of Botany, 57: 305-314

Ojiekpon, I. F., Eifediya, E. K., Ogieriakhi, S. N., Oghide, E. A., Fakuta, N. M. and Waizah, Y. (2011). Nursery Management operations for gum Arabic (Acacia senegal) seedling. ChemTech Journal, 7: 171-176

Steel, R.G.D. and Torrie, J. H. (1980). Principles and procedures of statistics: $A$ biometrical approach. $2^{\text {nd }}$ edition, McGraw-Hill, New York, USA, pp.20-90

SAS Institute (2002). SAS/STAT Guide for Personal Computer: version 9.0. SAS Institute Inc., Cary, NC, USA

Toma, B. (2013). Relationships between stem diameter at breast height $(\mathrm{DBH})$, tree height, crown length, and crown ratio of Vitellaria paradoxa C.F. Gaertn in the Nigerian Guinea Savanna. African Journal of Biotechnology, 12 (22): 3441-3446

Sukartini, T., Panjisakti, B. and Rudi, H. (2012). Analysis of heterosis and level of dominance in $\mathrm{F}_{1}$ mango (Mangifera indica L.). Journal of Agric. and Biological Science, 7(9):743-749. www. arpnjournals.com

Wynne, J. C., Emery, D.A. and Rice, P. H. (1970). Combining ability estimation in Arachis hypogaea L. II. Field performance of $F_{1}$ hybrids. Crop Science, 10(6): 713-715 